\title{
Host Range of Panicle Rice Mite Steneotarsonemus spinki Smiley (Acari: Tarsonemidae) in Sri Lanka
}

\author{
G.D.S.N. Chandrasena ${ }^{1, *}$, J.D.K.M. Jayawardane ${ }^{2}$, S.D. Umange ${ }^{1}$, A.D.B.U. Gunawardana ${ }^{1}$ \\ ${ }^{1}$ Regional Rice Research and Development Centre, Sri Lanka \\ ${ }^{2}$ District Secretariat, Sri Lanka
}

Copyright $(2016$ by authors, all rights reserved. Authors agree that this article remains permanently open access under the terms of the Creative Commons Attribution License 4.0 International License

\begin{abstract}
Panicle Rice Mite (PRM) is the most destructive mite pest attacking rice Oryza sativa (L.) in the Caribbean, Asia and Central America. Schoenoplectus articulates (L.), and the wild rice, Oryza latifolia Desv., were recorded as alternate hosts of PRM in some countries. A survey was conducted to identify alternate hosts of PRM in Sri Lanka and the observations were confirmed by transmission test. Of the 675 weed plants, consisting of 475 grasses and 200 sedges, observed for PRM, Sacciolepis interrupta, Echinocloa crus-galli and Leptochloa chinensis were determined as alternate hosts of PRM. The transmission tests conducted with common rice associated weeds namely, Cyperus rotundus (L.), C. kyllingia Endl., $C$. iria (L.), Leptochloa chinensis (L.), Echinocloa crus-galli (L.), Paspalum scrobiculatum (L.), Imperata cylindrica (L.), Sacciolepis interrupta (Willd.) and 5 wild rice species (Oryza nivara, O. echinigery, O. rufipogon, O. granulata and $O$. rizomatis) revealed that, $O$. nivara, S. interrupta, $E$. crus-galli and L. chinensis facilitate the survival and oviposition of PRM. In addition, O. nivara, S. interrupta found to be highly susceptible to PRM than E. crus-galli and L. chinensis.
\end{abstract}

Keywords Panicle Rice Mite, Alternate Hosts, Steneotarsonemus spinki, Tarsonemidae

\section{Introduction}

Steneotarsonemus spinki Smiley, the panicle rice mite (PRM) or rice sheath mite (RSM) is a microscopic creature and belongs to the family Tarsonemidae. It has been recorded as a pest of rice throughout rice-growing regions of Asia since the 1970s and in Cuba in 1997. Presently, it is considered as a serious pest of rice in Tropical Asia and Caribbean. [1] In USA the Genus Steneotarsonemus is listed as reportable /actionable pest.

PRM was recorded for the first time in Sri Lanka from the intermediate zone (annual rainfall 1,750 -2,000 $\mathrm{mm}$ ) of the country in 2000.[2, 3] Since then it spread quickly to other parts of the country.[4] At present, PRM has been recognized as the most important and destructive mite pest attacking rice in most of the rice growing areas in the island especially during the minor cropping season (or yala) (April - August) which is characterized by prolonged dry period and low rainfall. One predatory mite of $S$. spinki was identified in Sri Lanka as Laseosius spp. It was also found that, their occurrence is limited to the latter stage of the crop.[5]

The PRM live in the space between leaf sheaths and feeds on the adaxial surface of leaf sheaths and developing kernels. Damage symptoms can be detected by the presence of lesions on the leaf sheath with chocolate brown discoloration.[6] Damage to the leaf sheath reduces the photosynthetic potential of the plant and can have a negative effect on fertility.[7] Damage also results in sterile grains syndrome, which is characterized by loose and brownish flag leaf sheath, twisted panicle neck, impaired grain development with empty or partially filled grains with brown spots and panicles standing erect. The damage to grains showing sterility and malformed curved appearance is referred to as "parrot-beak".[1,6] It also damage rice plant indirectly by transmitting fungal pathogens such as the causal agents of sheath rot; Sarocladium oryzae and bacterial panicle blight; Burkholderia glumae. However, it is difficult to characterize and isolate the precise damage attributed to PRM as it is commonly associated and interacted with number of plant pathogens.[1] Yield losses in rice due to PRM damage has been estimated as 5\% - 90\% in a number of countries including Sri Lanka.[5, 6] Investigation on host range of $S$. spinki had been conducted in several countries. Ho and Lo [8] surveyed 73 weed species belonging to 17 plant families in and near paddy fields in Taiwan for the presence of PRM and concluded that food of the PRM was restricted only to rice. Hummel \& et al. [1] reviewed that, a similar study conducted by A. Jiang et al. (1994) in China revealed the preferred host for PRM was rice. According to her, American wild rice, Oryza latifolia (Desv.) has been identified as an alternate host for S. spinki in Costa Rica and Panama in 2005 by Sanabria and Aguilar. Furthermore, Cynodon dactylon (L.) Pers. (Poaceae) and Schoenoplectus articulatus (L.) Palla (Cyperaceae) have been reported as alternate hosts for PRM in India. [9, 10]

Being a recently emerged pest, host range studies on $S$. spinki have not yet been conducted in Sri Lanka. Therefore, a 
survey was conducted to identify the ecological host range of PRM in low country wet zone (annual rain fall $>2,500 \mathrm{~mm}$ ) of Sri Lanka during 2011 and the results were confirmed by a transmission test. Furthermore, additional transmission test was undertaken with wild rice varieties to determine their reaction to $S$. spinki.

\section{Materials and Methods}

\subsection{Survey on Host Range of $S$. spinki}

The survey was conducted in Kalutara and Colombo Districts in Sri Lanka during 2011. Objectives of this survey were to identify the naturally infested plant species in the rice ecosystem, count the number of PRM, their eggs and predatory mites in the infested plants and to identify the type of symptoms developed due to PRM damage. Plant samples were collected in weekly intervals from randomly taken quadrates $\left(0.09 \mathrm{~m}^{2}\right)$ from paddy fields and adjacent uplands. The collected samples were brought into the laboratory and separated as grasses, sedges and broad leafy plants. Then, all the leaf sheaths of grasses and sedges were observed under microscope for the presence of PRM. Here, each and every plant of grasses and sedges were subjected for observation. Then, the number of mites and number of eggs per 100 leaf sheaths were counted to determine the natural occurrence of PRM in each host. Infested leaf sheaths were also inspected for the presence of brown color lesions which are developed due to PRM damage.

\subsection{Transmission Test with Weeds}

Thirteen common weed species (grasses and sedges) grown in association with rice fields in the area were selected for the transmission test. They were Cyperus rotundus (L.), Cyperus kyllingia (Endl.), Cyperus iria (L.), Cyperus difformis (L.), Leptochloa chinensis (L.), Panicum repens (L.), Echinocloa crus-galli (L.), Paspalum scrobiculatum (L.), Paspalum distichum (L.), Imperata cylindrica (L.), Sacciolepis interrupta (Willd.), Isachne globosa (Thunb.) and Brachiaria mutica (Forssk.). Young healthy plants of above weed species were planted separately in pots as 3 plants per pot replicating 4 times. Two weeks later each test plant was artificially infested with PRM collected from field-infested rice plants by following the procedure below. Infestation rate was approximately 18 females and 9 males per pot. Eighteen days after artificial infestation, sampling was done three times in weekly intervals to determine the survival, growth rate and egg laying ability of PRM on test plants. Each sample was comprised with 5 tillers and all the sheaths in the sample were observed under microscope to count the number of mites and eggs

\subsection{Transmission Test with Wild Rice Species}

Seeds of 5 wild rice species namely, Oryza nivara, O. echinigery, O. rufipogon, O. granulata and O. rizomatis were sown separately in plastic pots. Number of replicates was four. Two weeks later, all the excess plants were removed leaving 5 healthy seedlings. At 10 weeks after sowing, each test plant was artificially infested with PRM following the same procedure. Infestation rate was 18 females and 9 males per pot. Growth rate of those wild rice plants were very slow when compared to the above weed plants. Therefore, sampling and data recording were started at 30 days after infestation and repeated in 20 day intervals until 90 days.

\subsection{Procedure for Artificial Infestation of RSM}

Sheaths of the field collected infested rice plants were cut in to $10 \mathrm{~cm}$ long pieces. Then, number of mite in each piece was counted by observing under the microscope and excess mites were removed by using a camel hair brush leaving the required number. After that, the piece with the known number of mites was inserted between a leaf sheath and culm of the test plant. Then, a little amount of water was poured gently from the open end of the inserted piece by using a jet bottle in order to ensure the introduction of mites into the test plant. (see figure.1)

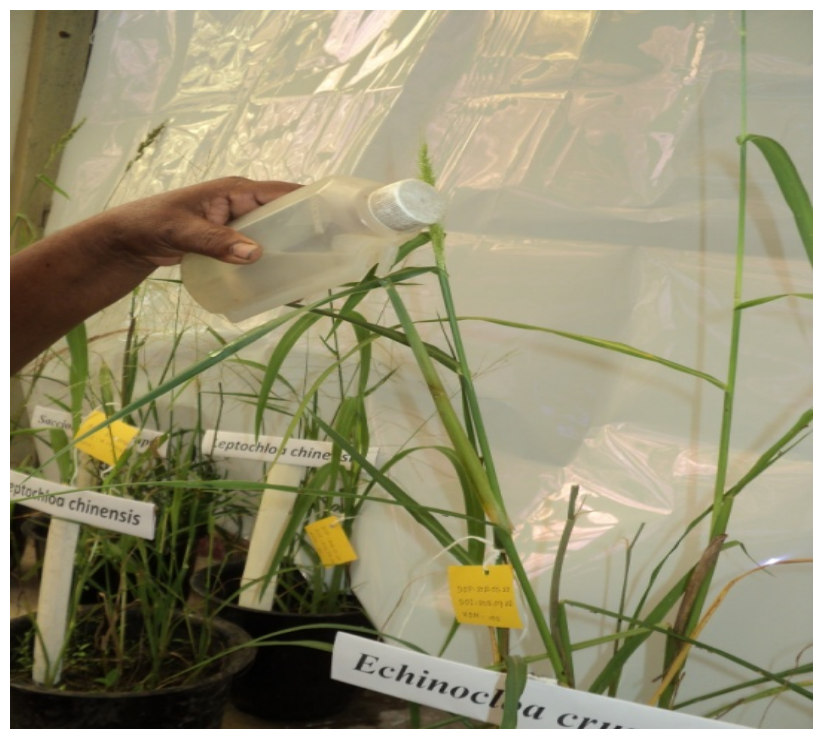

Figure 1. Artificial infestation of PRM in to test plants

\section{Results and Discussion}

\subsection{Natural Infestation of $S$. spinki in Rice Ecosystem}

In the survey, a total of 675 plants consisted of 475 grasses and 200 sedges were observed for the presence of PRM and its predatory mite. Of the weeds observed, 9 species were belonged to the family poaceae and 4 to the family cyperaceae (Table 1). According to the results E.crus-galli and $L$. chinensis were the most common poaceous weeds prevalent in the region followed by S.interrupta, $P$. repens and I. globosa while the most common sedges were $C$. kylingia and C. rotundus. 
Out of the 13 species surveyed, PRM were detected only in 3 grass species namely, $S$. interrupta (in Singhala; Beru weed), E. crus-galli (in singhala; maruk) and L. chinensis (in singhala; ashwa waliga). Of the 13 species observed the highest PRM were observed in S. interrupta (Table 1). The chocolate brown color lesions were not observed in any of the infested plant. Of the 440 and 411 leaf sheaths observed in E. crus-galli and L. chinensis, PRM infestation found to be very low as compared to $S$. interrupta

In spite of the large number of plants belong to $C$. rotundus, C. kyllingia, C. irria and C. difformis observed no evidence of the presence of PRM infestation recorded, indicating that, these sedges are not preferred by the pest under the conditions in the region. However, Hummel \& et al. [1] reviewed that, $C$. iria act as an alternate host for PRM in India. The number of sheaths observed in P. scrobiculatum, $P$. distichum and I. cylindrica (24, 18 and 12 respectively) may be inadequate to draw any conclusion to suggest that these plants are not host to PRM.

The predatory mite Laseosius spp was not detected in any plant surveyed.

\subsection{Population of PRM in Artificially Infested Weeds}

Results of transmission test revealed that, PRM are able to feed and breed on S. interrupta, E. crus-gali and L. chinencis (Table 2). PRM population in $S$. interrupta was very high as compared to other two hosts. Egg population also showed the same trend indicating its high preference to the pest.
Furthermore, symptom of chocolate brown color lesions were also shown by the infested $S$. interrupta sheaths. (see figure 2) As a whole, it can be stated that, results of the transmission test is in conformity with the survey results. As far as the management of PRM is concerned, destruction of these weeds hosts in paddy fields and adjacent uplands is very important.

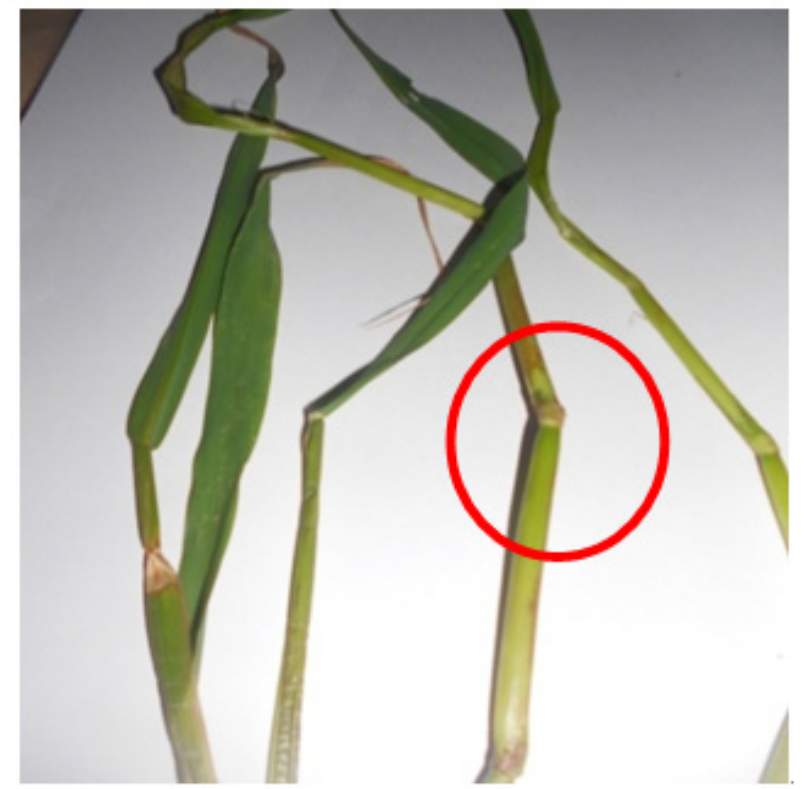

Figure 2. Panicle Rice Mite damage lesions on the Sacciolepis interrupta leaf sheaths

Table 1. Natural infestation of Panicle Rice Mite in weeds of rice ecosystem during 2011 at Kalutara and Colombo Districts in Sri Lanka

\begin{tabular}{|c|c|c|c|}
\hline Plant species & Total number of sheaths observed & Number of PRM / 100 sheaths & Number of eggs / 100 sheaths \\
\hline Cyperus iria & 45 & 0 & 0 \\
Cyperus kylingia & 163 & 0 & 0 \\
Cyperus rotundus & 144 & 0 & 0 \\
Cyperus difformis & 36 & 0 & 0 \\
Echinochloa crus-galli & 440 & 3 & 1 \\
Leptochloa chinensis & 411 & 1 & 0 \\
Panicum repens & 97 & 0 & 0 \\
Sacciolepis interrupta & 180 & 42.46 & 0 \\
Brachiaria mutica & 4 & 0 & 0 \\
Isachne globosa & 60 & 0 & 0 \\
Paspalum scrobiculatum & 24 & 0 & 0 \\
Paspalum distichum & 18 & 0 & 0 \\
Imperata cylindrica & 12 & 0 & 0 \\
\hline
\end{tabular}

Table 2. Panicle Rice Mite populations in artificially infested weed species at Bombuwela in Kalutara District in Sri Lanka during 2011

\begin{tabular}{|c|c|c|c|c|c|c|}
\hline \multirow{2}{*}{ Plant species } & \multicolumn{3}{|c|}{ PRM /100 sheaths* } & \multicolumn{3}{|c|}{ PRM eggs / 100 sheaths* } \\
\hline & 18 DAI & 25 DAI & 32 DAI & 18 DAI & 25 DAI & 32 DAI \\
\hline Cyperus iria & 0 & 0 & 0 & 0 & 0 & 0 \\
\hline Cyperus kylingia & 0 & 0 & 0 & 0 & 0 & 0 \\
\hline Cyperus rotundus & 0 & 0 & 0 & 0 & 0 & 0 \\
\hline Cyperus difformis & 0 & 0 & 0 & 0 & 0 & 0 \\
\hline Echinochloa crus-galli & 4.4 & 2 & 0 & 6.66 & 2 & 4.34 \\
\hline Leptochloa chinensis & 6.34 & 15.78 & 2.0 & 9.5 & 5.3 & 0 \\
\hline Sacciolepis interrupta & 150 & 77.3 & 54 & 71.42 & 32 & 37 \\
\hline Panicum repens & 0 & 0 & 0 & 0 & 0 & 0 \\
\hline Brachiaria mutica & 0 & 0 & 0 & 0 & 0 & 0 \\
\hline Isachne globosa & 0 & 0 & 0 & 0 & 0 & 0 \\
\hline Paspalum scrobiculatum & 0 & 0 & 0 & 0 & 0 & 0 \\
\hline Paspalum distichum & 0 & 0 & 0 & 0 & 0 & 0 \\
\hline Imperata cylindrica & 0 & 0 & 0 & 0 & 0 & 0 \\
\hline
\end{tabular}


Table 3. Panicle Rice Mite populations in artificially infested wild rice species at Bombuwela in Kalutara District in Sri Lanka during 2011

\begin{tabular}{|c|c|c|c|c|c|c|c|c|}
\hline \multirow{2}{*}{ Plant species } & \multicolumn{3}{|c|}{ PRM /100 sheaths* } & \multicolumn{4}{c|}{ PRM eggs / 100 sheaths* } \\
\cline { 2 - 9 } & 30 DAI & 50 DAI & 70 DAI & 90 DAI & 30 DAI & 50 DAI & 70 DAI & 90 DAI \\
\hline O. nivara & 667 & 129 & 579 & 341 & 389 & 56 & 372 & 304 \\
O. echinigery & 5 & 0 & 0 & 0 & 0 & 0 & 0 & 0 \\
O. rhizomatis & 0 & 0 & 0 & 0 & 0 & 0 & 0 & 0 \\
O. rufipogon & 0 & 0 & 0 & 0 & 0 & 0 & 0 & 0 \\
\hline
\end{tabular}

* Mean of 4 replicates; DAI: days after infestation

\subsection{Population of PRM in Artificially Infested Wild Rice Species}

Because of poor germination in O. granulata observations were made only from the other 4 varieties. It was found that, among the test wild rice species, $O$. nivara and $O$. echinigery have facilitated the survival of PRM (Table 3). Though PRM were detected in both the species, the former has recorded very higher number until 3 months from the infestation date. The results also revealed that, O. nivara is a good host for PRM for their breeding. Furthermore, brown discolorations were also observed in infested $O$. nivara leaf sheaths. Although the literature indicates that the PRM is confined to $O$. sativa the results showed that $O$. nivara is vulnerable to the pest as $O$. sativa.

The results suggest that $O$. nivara is an alternate host of PRM and that precaution to be taken when using this wild rice in varietal improvement in countries where PRM is a major pest problem. There is a need to study the susceptibility of different cultivated rice varieties to PRM.

\section{Conclusions}

Among the weed species in rice ecosystem in Sri Lanka, Sacciolepis interrupta act as an alternate host of the Panicle Rice Mite (Steneotarsonemus spinki; Tarsonemidae), while Echinochloa crus-galli and Leptochloa chinensis play minor roles. Destruction of these species in paddy fields and surrounding uplands is very important in management of PRM. The other predominant weeds found in association with rice crop namely Cyperus iria, C. kylingia, C. rotundus, C. difformis, Panicum repens, Brachiaria mutica, Isachne globosa, Paspalum scrobiculatum, Paspalum distichum and Imperata cylindrica found to be non-hosts to PRM. Of the wild rice species tested, $O$. nivara found to be the most vulnerable species to $S$. spinki.

\section{Acknowledgements}

Authors wish to acknowledge Prof. L. Nugaliyadde, Retired Entomologist, Rice Research and Development Institute, Sri Lanka for his constructive suggestions to improve the manuscript. Authors also wish to acknowledge Department of Agriculture, Sri Lanka for providing funds and facilities to do the research at Regional Rice Research Centre, Bombuwela. Authors' thanks are also due to K.A.C.
Rasanjalee and W.M.P.K.Wanigasuriya for the technical assistance given.

\section{REFERENCES}

[1] Hummel, N.A., Castro, B.A., McDonald, E.M., Pellerano, M.A and Ochoa R., The panicle rice mite, Steneotarsonemus spinki Smiley, a re-discovered pest of rice in the United States, Crop Protection (2009) 1-14, 2009.

[2] Cabrera RI, Nugaliyadde L. y Mayra Ramos. Presencia de Hirsutilla nodulosa sobre el ácaro tarsonémido del arroz Steneotarsonemus spinki en SRI Lanka, Manejo Integrado de Steneotarsonemus spinki, Smiley Resultados de. In Encuentro Internacional de Arroz 2002 La Habana Memorias Cuba Institute de Investigacones del Arroz 186-188,2002

[3] Nugaliyadde L., Dissanayake D.M.N., Amarasinghe A.A.L. and Abeysekera A.S.K.. New directions towards pest and disease management of rice in Sri Lanka: Proceedings of the Rice Symposium of the Department of Agriculture, Sri Lanka, 2005

[4] Pushpakumari A.S., Jayasundera D.M., Gunesekara D.M.K.W., Priyantha G.D.A., Kumari H.K.M. and De Silva P.H.J.. A potential pest of Rice in Sri Lanka. Annals of the Sri Lanka Department of Agriculture, Vol. 10, 353, 2008

[5] Pushpakumari, A.S., Nugaliyadde,L., Liyanage, K., Wickramasinghe, S. and Chandrasena, G.D.S.N. , A review of the rice pest management of Sri Lanka, Proceedings of Rice Congress of the Department of Agriculture, Sri Lanka held on 01-02, Dec., 2010, Plant Genetic Resource Centre, Gannoruwa, Peradeniya, Sri Lanka, 2010

[6] Steneotarsonemus spinki. Online available from http://en.wikipedia.org/ wiki/steneotarsonemus spinki

[7] Rice insect fact sheets, LSU Ag Centre Last Updated: 7/29/2013 Online available from www.lsuagcenter.com

[8] Ho, C-C.; Lo, K-C. The survey of the host ranges of Steneotarsonemus spinki (Acari: Tarsonemidae), National Science Council Monthly: 710: 1022-1028, 1979

[9] Rao, J and Prakash, A. Cynodon dactylon (Linn.) Pers. (Graminae): an alternate host of rice tarsonemid mite, Steneotarsonemus spinki Smiley. Journal of Applied Zoological Research 7, 50-51. 1996

[10] Rao, J., Prakash, A., 2002. Paddy field weed, Schoenoplectus articulatus (Linn.) Palla (Cyperaceae): a new host of tarsonemid mite, Steneotarsonemus spinki Smiley and panicle thrips, Haplothrips ganglbaureri Schmutz. J. Appl. Zool. Res. $13,174-175,2002$ 